\title{
DEVALUATION OF VALUES OR A CREATIVE NEED TO TRANSCEND INTO THE DEPTH?
}

\author{
Saulius KANIŠAUSKAS \\ Mykolas Romeris University, Institute of Humanities, Ateities g. 20, LT-08303, Vilnius, Lithuania
}

Received 23 August 2018; accepted 16 October 2018

\begin{abstract}
The recent decades have witnessed the increased society's attention to values based on welfare state and the economics of happiness, and this however becomes worrying. The term of "value" has started to be employed inarticulately and irresponsibly in public and even creative discourses. Thus, the question arises whether we face the process of devaluation of values? The paper reflects on contemporary tendencies of research in axiology and maintains that the increased focus on values appears not due to the lack of satisfying material needs but because of the unconscious creative need to transcend into the depth, that is because of ontological longing for something absolutely genuine.
\end{abstract}

Keywords: creativity, economics of happiness, scarcity, spirituality, values, virtues.

\section{Introduction}

It is noteworthy that due to the limited scope of the paper, most value-related problems will only be mentioned briefly because they were discussed rather extensively in other papers (Kanišauskas, 2014a, 2014b). The same applies to the problems of value-related creativity and creative technologies (Kanišauskas, 2012a, 2016). Also, it is worth mentioning that there are at least four hierarchically subordinated levels in creative processes (Kanišauskas, 2011). This paper focuses only on one of it, which is considered as a "normal creative process": redoing and recreating something by attributing absolutely new (not existent before) elements. It is worrying that these novel elements have been depreciating both the creative process (Kačerauskas, 2014) and value orientation (Pruskus, 2013a) in present multicultural postmodern society. However, these processes can be seen as related to ontological concern and creative need to transcend to the depth of the phenomena.

Though values in the sense of moral wealth have been widely discussed since the times of antiquity, the concept of value in the sense of how much something is worth started to be used only in the middle of the 19th century. At that time, the first value theories appeared

^Corresponding author. E-mails: sauliusk@mruni.eu; kansaulius@gmail.com 
and, at the beginning of the 20th century, they acquired the name of axiology ${ }^{1}$. Today their taxonomy is grounded on the philosophical ideas they follow. Traditionally, six historicallygrounded types have been distinguished: naturalistic psychologism, transcendentalism, personal ontology, cultural and historical relativism, sociologism and religious approach. The latter grounding of values is related to Christian heritage of the European culture.

At the end of the 20th century and the beginning of the 21 st century, the scholars of axiology looked back into Aristotle's ethics of virtue by relating it to creativity and expedience of human activities and pursuit for happiness (Boongaling, 2016; Pruskus, 2016). Thus, the theories of economics of happiness, seeking to establish social welfare (happiness), and new public management have emerged (Raipa, 2016; Guogis, 2011). The latter theory is oriented towards organizational culture, which should be based on the aggregate of widely spread basic values or at least on values, attitudes and norms which make the members of an organization one unit and allow implementing its aims and objectives (Patapas \& Labenskyte, 2011). Although both management strategies stand out as rather different, their aim is the same: to create the welfare state, which ensures the happiness of a human being and the society. In this way, the issues of values have become the focus of political, social, economic and legal discourses ${ }^{2}$.

Inevitably, the problem of values commands Lithuanian scholars' attention. Recently, the following scholars have attempted to tackle the issues of values in their papers and monographs: Vanda Aramavičiūtè (2005), Tomas Berkmanas and Edita Gruodyte (2014), Andrius Bielskis (2014), Saulius Kanišauskas (2012a, 2012b, 2012c, 2013a, 2013b, 2014a, 2014b), Bronislavas Juozas Kuzmickas (2013), Vilmantė Liubinienė (2002), Algis Mickūnas (2012), Alfonsas Algimantas Mitrikas (2005), Aistė Noreikaitė and Alvydas Jokubaitis (2015), Aleksandras Patapas and Gitana Labenskytė (2011), Albinas Plěšnys (2016a, 2016b), Valdas Pruskus (2013a, 2013b, 2015, 2016), Alvydas Raipa (2016), Romanas Vasiliauskas (2005), etc.

These theoretical discussions are largely related to the already mentioned orientation to creativity and to values in development of the welfare state. Also, it is noteworthy that it has conquered the media and it has become the buzzword in almost every politician, economist, manager, artist's speech.

However, they do not overstep the boundaries of this word and only sometimes they add that they mean intrinsic values but not mention which exactly. If they specify them, it turns out that they are neither intrinsic nor systemic values necessary for management. They are instrumental values, which are only attributive and hardly place anyone under obligation. Therefore, such frequent and irresponsible usage of the word "value" becomes worrying. The question arises whether the values are being devaluated. What are the real and underlying reasons for the frequent and irresponsible usage of this word? Can the so-called economics of happiness make a person truly happy and creative? Thus, this paper aims to seek the answers to these questions.

\footnotetext{
${ }^{1}$ Synonymic usage of the terms of the value theory and axiology is sometimes questionable. Some analytical philosophers argue that axiology is only part of the value theory, which is considered as independent and oriented to scientific cognition.

2 If we look at the website bookzz.org (see bookzz.org, 2018), for example, we can find more than 500 publications of the last decade dedicated to the issues of values. At least 20 of them are official documents or proceedings of international conferences and symposiums.
} 
The nature of the concept of values and its wide spectrum allow employing interdisciplinary and transdisciplinary methodology. Therefore, along with philosophical argument, social and political issues will inevitably be addressed. It has to be admitted that due to the limited space of the paper, some problems will be briefly overviewed but not analysed in-depth.

\section{The problems of the usage of the term "value" in research}

The problem of irresponsible and inarticulate usage of the word (or concept) "value" is first encountered when looking at the "value lists". For example, the university study programmes of leadership provide lists containing about 57 values, which should be aspired if you want to become an effective leader (Clear, 2017). Moreover, Steve Pavlina (2004) provides a 418-valuelist. Interestingly, what does a politician, a civil servant or a businessman mean when they say that the activity of their political party, organization, business enterprise or corporation is based on values but not, for example, on acknowledgement, progress, adaptability, candour, care, devotion, volunteering, team work or expected revenue? The question is serious because the mentioned values, even the revenue, are included in the "lists of values". These values are often explicitly declared in strategic documents. Every organization indicates their mission and vision along with the values they hold. The problem is that listing of the values does not have much in common with real practice, it is only used for creating a company's image (Arimavičiūte, 2005, pp. 105-119, 148-159). What are these "other", "special" values they have in mind when they emphasize some kind of abstract values along with the concrete ones?

This question will be addressed by providing an example of publicly accessible mission of Lithuanian National Radio and Television (LNRT) (lrt.lt, 2017). It enumerates the following values and moral principles: freedom of speech and ability to create, independence, impartiality, consideration for public interest and values, moral principles. Logically, the question arises what other values are besides the freedom of speech and ability to create, independence, etc., what moral principles they have in mind. Apparently, only the heads of LNRT can provide the answer. Or not. This is an example of increasing inarticulate and irresponsible talk about values in Lithuania. It is crucially important not to forget that language is not an instrument of reproduction of ideas but it has the power to influence and shape our mind, thinking and value attitudes (Pruskus, 2013a). This idea is supported by Steffen Roth (2013), who was investigating value orientations of corporations and business enterprises declared in their websites. He claims that most of them are copied from each other and the meaning of the declared values is scanty, not determined and not articulated. This leads to the idea that other countries face similar problems of values.

Perhaps, it will be overstated to claim that this inarticulate and irresponsible usage of the term "values" made theoreticians work on the systematization of the term usage. The process of systematization started when different senses of the term "values" were not used in public discourses yet. The first investigations by Wilhelm Windelband, Heinrich Rickert, Alexius Meinong, Max Scheler, Karl Robert Eduard von Hartmann, Nicolai Hartmann and Max Weber were published around 1890-1920. Later Martin Heidegger's, John Dewey's and Abraham Maslow's ideas and analytical and phenomenological approaches were particularly influential in developing value theories. Robert S. Hartman's The Structure of Value: Foundations of 
Scientific Axiology (1967) and "The Measurement of Value" (1973) became highly potent in systematization of values. These works following analytical tradition supplemented with phenomenological insights consolidated the concepts of intrinsic, extrinsic and systemic values and became the beacons of scientific (or formal) axiology (Clear Direction, Inc., 2001; Smith, 2014). However, systematization of values and their analysis were not the only focus of that time. There was a constant change and development of values and their evaluation (Clawson \& Vinson, 1978; Kanišauskas, 2014b). It has to be admitted that special attention to values was devoted at the end of the 20th century. In 1981, a 9-year-long international programme of European Values Study (2015) was launched and more than 70000 people of different nationalities and age groups participated in it by filling in a special questionnaire on values. This programme investigated the prevailing European life values. Also, it attempted to define the identity of Europe and its nations. Later, the programme extended to other countries and covered the periods of 1995-1998 and 1999-2001 (Mitrikas, 2005). Moreover, Liubiniene explored the change of values in the period when Lithuania was integrating into the European Union (2002). It is noteworthy that both sociological investigations were related to the quality of life as a possibility to choose an individual lifestyle and individual self-expression. This possibility was unequivocally related to the conception of the welfare state, which is grounded on liberal ideology.

Most of the mentioned investigations were performed not within the framework of classical value theories, not even within the framework of rather influential formal (scientific) axiology, but they were based on rather Rokeach Value Survey (1973) controversial modifications (Clawson \& Vinson, 1978). According to Milton Rokeach, terminal values are defined as the ones which a person adopts while pursuing the goals during their lifetime. Instrumental values are considered as personal abilities and talents, which allow achieving the goals. These definitions of terminal and instrumental values could be ascribed to the fields of philosophy and psychology if Rokeach had not presented a list of concrete terminal values such as a comfortable life, equality and equal opportunity for all, independence and free choice, physical and mental well-being, a world at peace and other. It is obvious that these concepts are integrally related to social and political philosophy but not to the problem of the meaning of life or psychology. Moreover, the definition of terminal values corresponds to instrumental values, which help accomplish life goals (being ambitious, competent, courageous, intellectual, responsible, loving, etc.). This substantial disagreement between the definition of terminal values and their specific manifestation is quite symptomatic. It shows a rather radical process of overestimation of values, which started in the 1960s. If classical value theories underlined moral values, then, in the era of postmodern capitalism, which adopts the ideology of immanent consumption and satisfying needs and even "production of needs" (Clawson \& Vinson, 1978; Rubavičius, 2010, pp. 34-39, 97-125), instrumental values are likely to be prioritized. Liubiniene (2002), following the prominent scholar Ronald Inglehart who investigated values of modernism and postmodernism, names this era as "postmaterialism". For example, she presents such values as self-discipline, social justice, friend-oriented social life and wealth and contends that they are not intrinsic values, they are only measures or instruments to satisfy our higher level needs. 
While discussing the findings of her research, Liubinienè (2002) underlines thather research is grounded on Shalom H. Schwartz's methodology, which might be considered as a modification of Rokeach's theory. Both Rokeach and Schwartz claim that values, which are related to activity motivating desirable goals, become evaluation criteria of human activities (Pléšnys, 2016b). Schwartz maintains that goal-oriented values are basic and universal. According to him, basic values are the ones which are recognized in every culture (thus, they are universal) and which motivate human behaviour and become goal-oriented (Schwartz, 2012). Although the scholar admits that individuals and social groups have different and constantly changing systems of values and that a large part of values comes in conflict or are hardly compatible ${ }^{3}$, he is convinced that his circular model of values constitutes universal a continuum of human motivations and it justifies universality of vital and other values.

However, a number of contemporary scholars disagree with Schwartz's ideas. At the end of the 20th century, a new postmodern thinking emerged and started to dominate the world. It utterly rejected any ideas of totality, generality and universality and it denied expedience existing in social sciences. On the contrary, it foregrounds diversity and its fragmentation, locality of events and even chaos. This thinking consolidated relativistic notion of value pluralism. Another version of cultural and historical value pluralism has remained immensely influential. According to it, moral norms and values depend on cultural and historical context; therefore, there are many equivalent (or at least irreducible to each other) value systems. This version finds its roots in culture studies based on historical insights (Kuzmickas, 2013, pp. 122-144). Even those contemporary scholars who reject relativistic attitude to values, have serious doubts about validity of Schwartz's arguments and pose a question whether universality is only assumed because some values are being protected on purpose by naming them as absolute, intrinsic, inherent, etc. (Baron \& Ritov, 2009). According to Jonathan Baron and Ilana Ritov (2009), the reasons for protecting "intrinsic" or "absolute" values lie in the attempt to differentiate the values identified with classical moral wealth from the values formed by business relationship and the culture of consumption and need satisfying. These scholars evaluate the attempt to differentiate the values in this way negatively. They maintain that moral choices and solutions should be determined by other alternatives, but not the abstract virtues though fundamental. Baron and Ritov present the findings of a sociological research, which illustrate that $22 \%$ of respondents would completely ban cloning or gene modification despite the fact how good the outcomes are. However, these respondents were absolutely convinced that this solution should be supported by all people. It is concluded that this minority of people would like to impose their moral convictions on the majority of people, not taking into consideration whether the majority supports it or does not. This is an essential disadvantage of deontological intuitions. As the scholars point out, teleological principal underlying utilitarianism is questionable because if we consider what is the most useful for the majority of people as the goal of activities, we will always face hardships in public politics: it is impossible to measure what is the most beneficial for the biggest number of people. Apparently, the scholars are against Schwarz's protected expedience and universality of values.

\footnotetext{
${ }^{3}$ For example, personal achievement is hardly compatible with benevolence towards another person. However, success and benevolence are considered as universal values.
} 
Stanley Riukas (1998), having analysed Aristotle's attitude to the dynamics of virtues and happiness, arrived at the conclusion that it is incorrect to contrast deontological and teleological attitudes towards values. He draws attention to the fact that in practice deontologybased intrinsic values often turn to teleology-based instrumental (goal-oriented) values and vice versa. Also, he points out that in the hierarchy of values, higher level values may become lower level values and vice versa. He describes the dynamics of values as reversibility of them and inability to understand this leads to relativistic conception of values.

Thus, it leads to a tentative conclusion that the reasons for irresponsible, inarticulate and excess usage of the term "value" are inevitably linked to scarcity of unambiguous answer to the question what contemporary values exist in real life and what their underlying principle is. Also, it has to be admitted that dominating relativistic conception of values and protection of them have a significant impact in contemporary society.

This conclusion however does not provide an answer why the term of "values" is so widely and frequently (and irresponsibly) used nowadays. On the one hand, we can accuse politicians, economists, artists and other people who discuss values in public discourses of not being familiarized with the principles of classical axiology ${ }^{4}$ and thus their terminology is not articulated properly and irresponsible. On the other hand, it may account for their ignorance but it does not explain their hypertrophied attention to values.

\section{Ontological scarcity and deontological longing}

The reference to the posed question can be found in the theory of basic values suggested by Schwartz's (2012). While writing about the nature of values, he underlined that values are beliefs related to inextricable questions and to unsatisfied action motivating needs. Moreover, having presented a list of basic values, he admitted that spirituality, which he earlier considered as a basic value, was removed from the list because in different cultures it is comprehended in different ways. Thus, though he points out that this concept is not universal ${ }^{5}$, he is positive that in most societies spirituality is acknowledged as one of the highest values up to now.

Maslow's ideas were influential in shaping the attitude that values arise out of needs and this is hardly questioned nowadays (Kuzmickas, 2013, pp. 8-11). In literature, fundamental needs such as vitality and security and such intrinsic needs for love, dependence, respect, self-actualization and sometimes transcendental needs are highlighted. The first group of fundamental needs (vitality and security) determines such values as life, health, security, pleasure, happiness, success, material wealth and others. The second group of intrinsic needs is related to ethical, aesthetical, religious and transcendental values. Also, excess values should be pinpointed. They arise from artificially formed excess needs, which can be described as protected values. They have existed in all times but particularly they started to flourish in the context of economics of happiness based on neoliberal ideology. It has to be admitted that not only excess values are protected but also the last decades witnessed the protection of vitality

\footnotetext{
${ }^{4}$ At least Lithuanian universities do not offer such study subjects as axiology or value theory.

${ }^{5}$ Alfonsas Vaišvila (2004) indicates that there are at least four historically grounded conceptions of spirituality: biological, logical, psychological and cultural.
} 
and security needs. It should not be wondered because, as Algirdas Degutis (2010) points out, nowadays the neoliberal ideology prevails in the Western world and surprisingly it is closely related to the resurgent Marxist ideology. The essence of the ideology lies in the idea that the most important need of the human being and society is to satisfy their needs for material wealth. Moreover, this ideology gives prominence to abstract ideas treating them as if they had an independent ontological status and it manifests through deeply rooted and protected values (Bielskis, 2014, pp. 34,44). The scarcity of material wealth and unequal sharing of it becomes the source of social tensions and conflicts. Thus, it is not surprising that the protected vision of welfare state and economics of happiness places a high value on relating the human and societal happiness to satisfying the need of material wealth and its fair distribution. By contrast, theoretical approaches, as it was mentioned previously, encourage turning back to Aristotelian understanding of happiness (eudemonia), which highlights "the activity of reason in accordance with virtue in a complete life" (Riukas, 1998). Alas, neither politicians nor economists take into consideration this suggestion. They should do this because the ideology of economics of happiness faces a serious issue whether it is fair. Sociological research has shown that the rise of income of people living in poverty (i.e. satisfying material needs) increases their satisfaction in life (it increases their "happiness"). This happens just to a certain extent. When the income reaches a particular level (when it reaches an average income of developed countries), the further income increase does not affect satisfaction in life ("happiness") significantly. This rather strange link between happiness and income increase was called the Easterlin paradox (Navaitis \& Gaidys, 2016). Therefore, it is legitimate to ask whether such protected values as material wealth with its happiness, success, benefit, etc. are really the most important for the human being. It is legitimate to ask whether the scarcity of satisfaction of fundamental needs leads to disappointment with life, the loss of the meaning of life and depression.

The term "scarcity" was not used incidentally. It takes us back to the previously mentioned Schwartz's idea that values are related to unsatisfied needs, that is the scarcity of health, security, pleasure, success, material wealth and other. But does the human being feel the lack only of these values? What about such values as attention, friendliness, love, respect, generosity, the sublime, fairness, etc.? Finally, do not we feel the lack of what Maslow called transcendental needs?

These questions might be regarded as rhetorical if not a study published by Lithuanian Culture Research Institute in 2016. The authors of the study The Phenomenon of Scarcity: Being, Man and Society (Leontjeva, Vainè, \& Vyšniauskaitè, 2016) are economists, managers, political scientists, sociologists, psychologists, philosophers and the clergy. They introduce the findings of the several-year project. The fact that the study was initiated by Lithuanian Free Market Institute, spreading and defending the ideas of liberalism and libertarianism, is worth taking into consideration. The phenomenon of scarcity of material values has become the basis of many economic theories (Šilenas \& Žukauskas, 2016). But the study showed that if we want to implement the economics of happiness and solve the Easterline paradox, we also lack other things. We feel scarcity of such wealth, which was mentioned by Aristotle and later developed by Thomas Aquinas in the Christian context. It is very important that quite often the concept of "scarcity" is understood in its negative sense, while it should be 
comprehended as seeking and longing for the good to acquire, that is the things we desperately need (Plèšnys, 2016a).

I would argue that this understanding of the concept of "scarcity" explains the Easterline paradox and irresponsible and inarticulate usage of the term "value". In the process of diminishing the scarcity of material values, that is when the most vital needs are satisfied and physical security is ensured, the other needs do not disappear. These needs underlie the values ascribed to the domain of intrinsic, spiritual values in axiology. If politicians do not name the values they write or speak about, it happens because of two reasons. The first reason has already been mentioned - the lack of philosophical education and awareness. The second reason is far more serious. Almost all people feel that the values of spiritual character do exist. But not all people dare admit this openly. If Schwartz, being a theoretician, was making excuses about the concept of spirituality not being universal, then not surprisingly the concepts of spirituality and transcendentalism are likely to be avoided in public secular discourses. It happens because the concepts have little in common with perceptual reality and, thus, they are pointless or they are related to religious beliefs, which might be unacceptable for a large part of the society.

The dissociation from spiritual values connected with transcendentalism does not mean that they do not exist. It has been mentioned that the conception of spiritual in the sense ("pajauta") of Numinosum is inseparable from deep respect toward transcendence, which might evoke both terror and fascination, and toward living beings, life, ground, grass, animals, people, that is the nature (Kanišauskas, 2013a). I have used the Lithuanian word "pajauta", which is problematic or even impossible to translate, not accidentally. This concept belonging to the field of aesthetics is defined as experiencing something significant and meaningful, and it manifests through emotions, imagination, associations and even extrasensory feelings (Mureika, 2016, pp. 62, 137-159). I would call it intuitive insight, whereas Povilas Aleksandravičius (2015, pp. 11, 25-29) names it as a transcendental movement to the depth. This transcendence is not necessarily overstepping a line between the material and the ideal, what ordinary people call as earthly and divine. Both Aleksandravičius (2015, p. 6) and Bielskis (2014, pp. 79-86) point out that it can also be understood as overstepping the line between $I$ and the Other, or in other words, it is a metaphysical transgression of one's limits. Admittedly, Bielskis relates the longing for metaphysical transgression to Emmanuel Lévinas' secular conception of consciousness, though Levinas (1994, p. 14) claimed that his original conception of transcendence was related to Biblical texts. But the most important is that the needs can be satisfied while metaphysical longing is impossible to satisfy due to its nature: we can only feel it, its object is implied and inarticulate but not rationally defined. It does not matter that the object is related to the immanent intuitive insight ("pajauta") of Numinosum or to transcendental movement to the depth wishing I and the Other to merge, to melt into each other, in other words, to unite. It is important that this metaphysical wish which can be called as ontological longing really exists and it inevitably leads to the vague and inarticulate usage of the term "values".

In other words, when we attempt to list all values related to the needs, some values will always remain overlooked, because it is impossible to explicate what is only felt, what is implied and what is a secular or religious metaphysical longing. In axiology, they are called instrumentally indeterminate universal intrinsic values. What they have in common is that they describe 
not what is, was or will be but what should be respected and valued and even what must be (Kuzmickas, 2013, p. 12). Therefore, when a politician, economist, clergyman or journalist says the word "values", not explicating what values they have in mind, we should understand that they mean what I have called the existential, ontological longing for what should or must be.

\section{Conclusions}

The reflections on the value problem lead to the conclusion that there are the certain reasons for the excess, irresponsible, inarticulate usage of the term "values". The first reason is the scarcity of an unambiguous answer to the question what contemporary values are in reality. Next, the presently dominating relativistic conception of values and often illegitimate protection of some values has a huge impact on such use of the term. Also, lack of adequate philosophical education and awareness play a significant role. Having taken everything into consideration, it should be pointed out that the principal reason for it is unconscious longing for what should and must be.

\section{References}

Aleksandravičius, P. (2015). Europos mąstymo kryptys ir ateitis. Vilnius: Mykolo Romerio universitetas. Aramavičiūte, V. (2005). Vertybès kaip gyvenimo prasmès pamatas. Acta Paedagogica Vilnensia, 14, 18-27.

Arimavičiūtè, M. (2005). Viešojo sektoriaus instituciju strateginis valdymas. Vilnius: Mykolo Romerio universitetas.

Baron, J., \& Ritov, I. (2009). Protected values and omission bias as deontological judgments. In B. Ross (Ed.), Psychology of learning and motivation (pp. 133-167). Vol. 50: Moral Judgment and Decision Making. D. Bartels, Ch. Bauman, L. Skitka, D. Medin (Serial Volume Eds.). New York: Academic Press.

Berkmanas, T. ir Gruodytė, E. (2014). Teisininkų etikos vertybių realumo ir modeliavimo problemos. Problemos, 85, 79-90.

Bielskis, A. (2014). Nešventas sakramentas: ideologija, tikejjimas ir išsilaisvinimo politika. Vilnius: DEMOS kritinès minties institutas.

bookzz.org. (2018). bookzz.org. Retrieved from http://ww12.bookzz.org/

Boongaling, J. I. K. (2016). Three problems for contemporary virtue ethics. Filosofija. Sociologija, 27(3), 206-213.

Clawson, C. J., \& Vinson, D. E. (1978). Human values: a historical and interdisciplinary analysis. Advances in Consumer Research, 5, 396-402.

Clear, J. (2017). Core values list. Retrieved from https://jamesclear.com/core-values

Clear Direction, Inc. (2001). Formal axiology. Retrieved from http://www.cleardirection.com/docs/ formalaxiology.asp

Degutis, A. (2010). Kaip galima liberalizmo tironija (pradžia). LOGOS: religijos, filosofijos, komparatyvistikos ir meno žurnalas, 64, 51-61.

European Values Study. (2015). About EVS. Retrieved from http://www.europeanvaluesstudy.eu/page/ about-evs.html

Guogis, A. (2011). Pažangaus Gerovės normatyvinio modelio paieškos Europos ir Lietuvos kontekste. Filosofija. Sociologija, 22(4), 365-372. 
Hartman, R. S. (1973). The measurement of value. Retrieved from http://strandtheory.org/images/Hartman_-_The_measurement_of_Value.pdf

Hartman, R. S. (1967). The structure of value: foundations of scientific axiology. Carbondale: Southern Illinois University Press.

Kačerauskas, T. (2014). Kūrybos visuomenès terminai ir sampratos. LOGOS: religijos, filosofijos, komparatyvistikos ir meno žurnalas, 78, 6-18.

Kanišauskas, S. (2011). Autopoiesis kaip savikūra ir kūrybos ištakos. Santalka: filosofija, komunikacija, 19(2), 45-53.

Kanišauskas, S. (2012a). Kūrybos komunikacija: introspektyvi analizè ir vertybès. Santalka: filosofija, komunikacija, 20(2), 101-109.

Kanišauskas, S. (2012b). Šeimos ir tautos tapatumas kaip socialinis kodas ir vertybė. Socialiniu mokslu studijos, 4(3), 937-952.

Kanišauskas, S. (2012c). „Šeimos kazusas“, egalitarizmas ir žmogiškosios vertybès. Socialinių mokslu studijos, 4(2), 489-501.

Kanišauskas, S. (2013a). Filosofinès socialinio modeliavimo problemos: teorija, praktika, siekiai, vertybès. Vilnius: Mykolo Romerio universitetas.

Kanišauskas, S. (2013b). Vertybès dvasingume ir dvasingumo vertybès. Socialinių mokslu studijos, 5(3), 709-719.

Kanišauskas, S. (2014a). Aksiologijos įvadas. Vilnius: Mykolo Romerio universitetas.

Kanišauskas, S. (2014b). Vertybių erdvèlaikis: kaitos ir pastovumo problema. Filosofija. Sociologija, 25(3), 164-173.

Kanišauskas, S. (2016). Creative technologies entrapped by instrumental mind. Filosofija. Sociologija, 27(1), 40-50.

Kuzmickas, B. (2013). Vertybès kultūru kontekstuose. Vilnius: Mykolo Romerio universitetas.

Leontjeva, E., Vainė, A. ir Vyšniauskaitè, M. (sud.). (2016). Stokos reiškinys: būtis, žmogus ir bendruomenè. Vilnius: Lietuvos laisvosios rinkos institutas, Lietuvos kultūros tyrimų institutas.

Lévinas, E. (1994). Etika ir begalybè. Vilnius: Baltos lankos.

Liubiniene, V. (2002). Change or values in Lithuania in the Process of European Integration. Sociologija: mintis ir veiksmas, 2, 50-60.

lrt.lt. (2017). Values and principles of activity. Retrieved from https://www.lrt.lt/en/about/values

Mickūnas, A. (2012). Social value and individual worth. Vilnius: Mykolas Romeris University.

Mitrikas, A. A. (2005). Svarbiausios gyvenimo vertybės šių dienų pasaulyje. Filosofija. Sociologija, 2, 40-45.

Mureika, J. (2016). Estetologijos įžvalgos. Vilnius: Lietuvos edukologijos universiteto leidykla.

Navaitis, G. ir Gaidys, V. (2016). Laimès ekonomikos nuostatų sklaida Lietuvos visuomenëje. Filosofija. Sociologija, 27(2), 125-131.

Noreikaite, A. ir Jokubaitis, A. (2015). Dworkino alternatyva Berlino vertybių pliuralizmui. Problemos, 88, 153-165. https://doi.org/10.15388/Problemos.2015.88.8485

Patapas, A. ir Labenskytė, G. (2011). Organizacinès kultūros ir vertybių tyrimas N apskrities valstybinėje mokesčių inspekcijoje. Viešoji politika ir administravimas, 10(4), 589-603.

Pavlina, S. (2004). List of values. Retrieved from https://www.stevepavlina.com/blog/2004/11/list-ofvalues/

Plèšnys, A. (2016a). Stoka ir jos vertybiniai aspektai. Iš E. Leontjeva, A. Vainė ir M. Vyšniauskaitė (Sud.). Stokos reiškinys: būtis, žmogus ir bendruomene (pp. 39-53). Vilnius: Lietuvos laisvosios rinkos institutas, Lietuvos kultūros tyrimų institutas. 
Plèšnys, A. (2016b). Virtues and values as behavior determinants. Filosofija. Sociologija, 27(3), 222-230.

Pruskus, V. (2015). Individo laikysenos valstybės puoselejjamų vertybių ir tikslų atžvilgiu etiniai aspektai. Filosofija. Sociologija, 26(1), 28-36.

Pruskus, V. (2016). Individo siekiai ir vertybiu pasirinkimas. Filosofija. Sociologija, 27(3), 199-205.

Pruskus, V. (2013a). Vertybės ir kultūrinis identitetas komunikacijos kontekste (pradžia). LOGOS: religijos, filosofijos, komparatyvistikos ir meno žurnalas, 76, 182-188.

Pruskus, V. (2013b). Vertybès ir kultūrinis identitetas komunikacijos kontekste (pabaiga). LOGOS: religijos, filosofijos, komparatyvistikos ir meno žurnalas, 77, 159-166.

Raipa, A. (2016). Viešosios vertès kūrimas naujojo viešojo valdymo struktūrose. Viešoji politika ir administravimas, 15(2), 220-234.

Riukas, S. (1998). Inherent and instrumental values in ethics. Paideia: philosophy of values. Retrieved from https://www.bu.edu/wcp/Papers/Valu/ValuRiuk.htm

Rokeach, M. (1973). The nature of human values. New York: Free Press.

Roth, S. (2013). Common values? Fifty-two cases of value semantics copying on corporate websites. Human Systems Management, 32(4), 249-265.

Rubavičius, V. (2010). Postmodernusis kapitalizmas. Kaunas: Kitos knygos.

Schwartz, Sh. H. (2012). An overview of the Schwartz theory of basic values. Online Readings in Psychology and Culture, 2(1), 1-20. https://doi.org/10.9707/2307-0919.1116

Smith, R. K. (2014). Axiology and attorney compensation. Retrieved from http://www.zeroriskhr.com/ pdfs/support/hidden/clients/samples/axiology-and-attorney-compensation.pdf

Šilènas, Ž. ir Žukauskas, V. (2016). Scarcity as the foundation of economics. Iš E. Leontjeva, A. Vainè ir M. Vyšniauskaitė (Sud.), Stokos reiškinys: būtis, žmogus ir bendruomené (pp. 293-314). Vilnius: Lietuvos laisvosios rinkos institutas, Lietuvos kultūros tyrimų institutas.

Vaišvila, A. (2004). Kultūrologinè dvasingumo samprata. Iš J. Morkūnienė (Sud.), Šiuolaikiné filosofija: globalizacijos amžius (pp. 72-87). Vilnius: Lietuvos teisès universitetas.

Vasiliauskas, R. (2005). Vertybių ugdymo teoriniai ir praktiniai aspektai. Acta Paedagogica Vilnensia, 14, 8-17.

\title{
VERTYBIŲ DEVALVACIJA AR KŪRYBINIS POREIKIS TRANSCENDENTUOTI t GELMĘ?
}

\author{
Saulius KANIŠAUSKAS
}

\section{Santrauka}

Pastaraisiais dešimtmečiais su gerovés valstybe ir laimès ekonomika siejamas smarkiai išaugęs visuomenès dèmesys vertybėms ima kelti nerimą. Terminas vertybé viešuosiuose ir net kūrybiniuose diskursuose pradètas vartoti neartikuliuotai, neatsakingai. Todèl kyla klausimas - ar neprasidejo vertybių devalvacijos procesas? Straipsnyje apžvelgiamos šiuolaikinių vertybinių tyrimų tendencijos ir parodoma, kad dèmesys vertybėms kyla ne tik dèl vis dar esančios materialių poreikių patenkinimo stokos, bet ir dèl neįsisąmoninto kūrybinio poreikio transcendentuoti ì gylí, ontologinio ilgesio to, kas iš tiesų yra tikra.

Reikšminiai žodžiai: kūrybiškumas, laimès ekonomika, stoka, dvasingumas, vertybès, dorybès. 